\title{
PERAN MAJELIS TA'LIM SELAPARANG DALAM PEMBINAAN KEAGAMAAN MASAYARAKAT
}

\section{Muhammad Munir}

UIN Mataram

Emai: muhammadmunir.1007@gmail.com

\begin{abstract}
Abstrak: Tujuan penelitian ini adalah untuk mengetahui peran Majelis Ta'lim Selaparang dalam pembinaan keagamaan masyarakat dan mengetahui hambatan dan solusi dalam pembinaan keagamaan masyarakat. Penelitian ini menggunakan pendekatan kualitatif dengan jenis penelitian deskriptif kualitatif. Teknik pengumpulan data menggunakan observasi, wawancara dan dokumentasi. Sedangkan analisis data menggunakan reduksi data, penyajian data, dan verification. Adapun hasil penelitian mengenai peran Majelis Ta'lim Selaparang dalam pembinaan keagamaan masyarakat adalah majelis ta'lim sebagai tempat meningkatkan pengetahuan keagamaan, pendidikan seumur hidup berbasis masyarakat, pendidikan gratis, dan menjalin silaturrahim. Hambatan-hambatan dalam penyelenggaraan ta'lim ini terdapat pada dua faktor, yaitu internal dan eksternal. Pertama, faktor internal antara lain pengasuh atau jama'ah yang sakit, adanya musibah. Kedua, faktor eksternal antara lain penyelenggaraan PHBI dan begawe.
\end{abstract}

Kata Kunci: Majlis ta'lim, pembinaan keagamaan

Title: The Role of the Majelis Ta'lim Selaparang In Developing Community Religious

Abstract: The purpose of this study is to find out the role of the Majelis Ta'lim Selaparang in developing community religious; know the obstacles and solution tosolving these problems. This study uses a descriptive qualitative approach. The collecting data uses observation, interview and documentation. While data analysis uses data reduction, data presentation and verification. The results of this study found that the Majelis Ta'lim Selaparang as a place to increase religious knowledge, establish friendship, community-based education, for longlife, and all for free. The obstacles in the implementation are in two factors, namely internal and external factors. First, internal factors include caregivers or pilgrims who are sick, the accident. Second, external factors include organizing Islamic holidays (PHBI) and traditional Sasak wedding rituals (begawe).

Keywords: Majelis ta'lim, developing religious 


\section{PENDAHULUAN}

Majelis ta'lim merupakan tempat berlangsungnya pendidikan Islam yang membawa misi dakwah Islamiyah, karena tujuannya tidak lain adalah agar nilai-nilai Islam terwarisi oleh setiap insan dan mengkarakter dalam dirinya dan direalisasikan dalam perilaku kehidupan sehari-hari. Bila nilai-nilai Islam telah melembaga pada masing-masing individu, maka agama ini menjadi tegar di dunia, tersebar di seluruh lapisan dunia dan fungsi agama Islam sebagai rahmatan lil 'alamin dapat dibuktikan. ${ }^{1}$

Secara sederhana tujuan majelis ta'lim adalah tempat berkumpulnya manusia yang didalamnya membahas pengetahuan agama serta terwujudnya ikatan silaturrahmi guna meningkatkan kesadaran masyarakat tentang pentingnya peranan agama dalam kehidupan sehari-hari. Dengan adanya majelis ta'lim masyarakat dilatih menjadi pribadi yang mandiri dalam menjalankan tugas sebagai khalifah Allah, dan juga dilatih agar bisa menyelesaikan masalah terkait urusan agama. Melihat dari perkembangan teknologi saat ini, hampir sebagian besar masyarakat Islam sudah melupakan yang namanya menuntut ilmu, mereka merasa cukup dengan mencari di internet tanpa mengkaji secara mendalam melalui kitab-kitab atau bertanya pada ahli agama.

Majelis Ta'lim Selaparang merupakan salah satu majelis ta'lim yang berada di desa Babussalam, Lombok Barat sejak tahun 1985. Majelis ta'lim ini diasauh oleh Ustadz Sami'un. Jamaah majelis ta'lim ini terdiri dari semua kalangan, tua, muda, laki-laki, perempuan, yang tidak pernah merasakan pendidikan formal (sekolah formal), apalagi sampai yang menjadi sarjana. ${ }^{2}$ Keberagaman jamaah ini menandakan Majelis Ta'lim Selaparang mempunyai peran dalam membina kehidupan beragama masyarakat. Majelis ini berdiri atas kesadaran dari warga masyarakat Dusun Bile Kedit tentang kurangnya ilmu agama yang mereka miliki. Mereka meminta kepada ustadz Sami'un sebagai salah satu tokoh masyarakat yang keilmuan keagamannya cukup mumpuni agar meluangkan waktunya untuk membimbing dan membina warga masyarakat dalam bidang keagamaan, seperti ibadah dan mu'amalah. ${ }^{3}$ Konsistensi dalam memberikan pendidikan dan pelayanan kepada masyarakat juga eksisitensi majelis ta'lim ini menarik untuk dibahas merujuk kepada banyak faktor yang menunjang dan juga menghambat perjalanan panjangnya yang sudah tak muda lagi.

\footnotetext{
${ }^{1}$ Hasbullah, Sejarah Pendidikan Islam di Indonesia (Lintasan Sejarah Pertumbuhan dan perkembangan), (Jakarta: PT. Raja Grafindo Persada 1995), h. 79.

${ }^{2}$ Ustadz Sami'un, Observasi, Bile Kedit, 05 September 2018.

${ }^{3}$ Ustadz Sami'un, Wawancara, Bile Kedit, 06 September 2018.
} 


\section{METODE PENELITIAN}

Penelitian ini menggunakan pendekatan kualitatif 6 , menghasilkan data deskriptif berupa kata-kata tertulis atau lisan dari orang-orang dan perilaku yang dapat diamati. Tujuan dari penelitian desktriptif ini adalah untuk membuat deskripsi, gambaran-gambaran atau lukisan secara sistematis, faktual dan akurat mengenai fakta-fakta, sifat-sifat serta hubungan antar fenomena yang diselidiki. ${ }^{8}$

Pengumpulan data melalui pengamatan, wawancara, dan studi dokumentasi. Observasi dilakukan untuk mendapatkan data peran Majelis Ta'lim Selaparang dalam pembinaan keagamaan masyarakat, peneliti mempersiapkan buku catatan harian lapangan untuk menggambarkan kejadian-kejadian kronologis. Wawancara (interview), dalam penelitian ini, menggunakan wawancara tidak terstruktur, yakni pertanyaan-pertanyaan yang diajukan secara bebas kepada pengasuh majelis ta'lim dan Jamaah, tentunya pertanyaan yang diajukan tidak keluar dari rumusan masalah. Fungsi wawancara tidak terstruktur yang digunakan adalah peneliti memperoleh data yang sesuai dengan konsep yang sudah disediakan namun pertanyaannya boleh dimulai dari pertanyaan yang mana saja. Dokumentasi, dokumentasi adalah ditujukan untuk memperoleh data langsung dari tempat penelitian, meliputi bukubuku yang relevan, peraturan-peraturan, laporan kegiatan, foto-foto, film dokumenter, data yang relevan penelitian. Teknik analisis data yang digunakan adalah deskriptif naratif. Teknis ini menurut Milles dan Huberman dalam Jama'an Satori dan Aan Qomariah diterapkan melalui tiga alur, yaitu: reduksi data (reduction), penyajian data (data display), conclusion drawing/ verification.

\section{HASIL PENELITIAN DAN PEMBAHASAN}

\section{Peran Majelis ta'lim Selaparang dalam Pembinaan Keagamaan Masyarakat}

Pendidikan merupakan salah satu aspek yang memiliki peranan penting dalam membentuk generasi masa mendatang. Dengan pendidikan diharapkan dapat menghasilkan manusia yang berkualitas dan bertanggung jawab serta mampu mengantisipasi masa depan. Pendidikan dalam maknanya yang luas senantiasa menstimulir dan menyertai perubahanperubahan dan perkembangan manusia. Oleh karena itu, upaya pendidikan senantiasa menghantarkan dan membimbing perubahan dan perkembangan hidup serta kehidupan umat manusia. ${ }^{17}$

${ }^{6}$ Tohirin, Metode Penelitian Kualitatif dalam Pendidikan dan Bimbingan Konseling, (Jakarta: PT. Raja Grafindo, 2012), h.

3.

${ }^{8}$ Nazir, Metode Penelitian, (Bogor: Ghalia Indonesia, 2005), cet. Ke-6, h. 54.

${ }_{9}^{9}$ Djam'an Satori dan Aan Qomariah, Metode..., h. 218.

${ }^{17}$ Ahmad Marzuki, "Dinamika Dan Peran Majelis Ta'lim Dalam Meningkatkan Pengetahuan Keagamaan Di Wilayah Suku Tengger” Jurnal Mafhum, Volume 1 Nomor 2, November 2016, h 188. 
Pembinaan keagamaan adalah tugas suci yang dibebankan kepada setiap muslim dimana saja ia berada. Hal ini termaktub dalam al-Quran dan as-Sunnah Rasulullah SAW, kewajiban dakwah menyerukan, dan menyampaikan agama Islam kepada masyarakat. ${ }^{18}$

Majelis ta'lim merupakan tempat menimba ilmu yang bersifat fleksibel, berperan mewujudkan pendidikan sepanjang hayat yang berbasis masyarakat sehingga mampu membentuk karakter pesertanya. Tujuan penyampaian pendidikan di majelis ta'lim di antaranya yaitu sebagian besar adalah tujuan pada aspek pengetahuan keagamaan (rohani) dan aspek pengetahuan umum (akal), serta sebagian kecil sekali ditujukan pada aspek keterampilan. Oleh karena itu, tujuan pendidikan di majelis ta'lim yaitu dapat membentuk jema'ah agar memiliki karakter beriman dan bertakwa, serta karakter berilmu pengetahuan. ${ }^{19}$

Kalau ditelaah secara mendalam, majelis ta'lim selain sebagai tempat menimba ilmu, majelis ta'lim juga berperan mewujudkan pendidikan sepanjang hayat berbasis masyarakat agar mampu membentuk karakter pesertanya dalam aspek keagamaan (rohani), aspek keterampilan (akal), dan membentuk karakter beriman dan bertakwa, serta karakter berilmu pengetahuan.

Peranan pembinaan keagamaan merupakan sebuah kegiatan, ajakan, baik dalam bentuk lisan, tulisan, tingkah laku dan sebagainya, dimana peranan tersebut dapat dilakukan secara sadar dan terencana, tentunya dalam upaya mempengaruhi orang lain baik secara individu maupun secara kelompok, supaya timbul dalam dirinya sebuah kesadaran, baik dalam sikap penghayatan maupun pengalaman terhadap ajaran agama Islam, dan sebagai pesan yang disampaikan kepada nya tanpa ada unsur paksaan dari siapapun. Pembinaan keagamaan dapat menimbulkan berbagai peristiwa ditengah masyarakat yang harmoni, yang menegangkan, yang kontroversial, bisa juga melahirkan berbagai pemikiran, baik pemikiran yang moderat maupun yang ekstrem, yang sederhana maupun yang rumit, yang parsial maupun yang komprehensif. ${ }^{20}$

Peranan dalam pembinaan keagamaan mencakup segi-segi yang sangat luas, seperti mengajak orang yang belum memeluk Islam untuk masuk Islam, usaha amar ma'ruf nabi mungkar serta usaha-usaha perbaikan dan pembangunan dalam rangka merealisasikan ajaran Islam dalam segenap segi kehidupan. Sebagaimana firman Allah SWT dalam surat Al-Nahl ayat 125, yang artinya: "Serulah (manusia) kepada jalan Tuhanmu Dengan hikmat dan pengajaran Yang baik, dan berdebatlah dengan mereka dengan cara yang baik. Sesungguhnya

${ }^{18}$ Ahmad Syafi'i Ma'arif, Islam dan Politik : Upaya Membingkai Peradaban, (Jakarta :

Pustaka Dinamika, 1999), h 15.

${ }^{19}$ Helmawati, Pendidikan..., h. 168.

20 Achmad Mubarok, Psikologi Dakwah, (Jakarta : Prenada Media Group, 2009), h. Vii 
Tuhanmu, Dialah yang lebih mengetahui siapa yang sesat dari jalan-Nya dan Dialah yang lebih mengetahui siapa yang mendapat petunjuk."'21

Pembinaan keagamaan sekarang sudah berkembang menjadi satu profesi, yang menuntut skill, planning dan manajemen yang handal. Untuk itu diperlukan sekelompok orang yang secara terus menerus mengkaji, meneliti dan meningkatkan aktivitas secara professional tersebut. $^{22}$

Berikut beberapa peran majelis ta'lim Selaparang yang terdapat dalam pembinaan keagamaan masyarakat, diantaranya yaitu:

1. Peningkatan Pengetahuan Keagamaan

Meningkatkan pengetahuan tentang keagamaan tidak hanya bisa dilaksanakan di lembaga pendidikan formal seperti sekolah agama, peningkatan pengetahuan keagamaan juga bisa didapatkan dari lembaga pendidikan nonformal seperti majelis ta'lim. Hal ini dipertegas oleh Helmawati dalam bukunya:

Pengetahuan keagamaan yang diperoleh dari majelis ta'lim dapat membantu meningkatkan keimanan jemaah. Sekitar 90 persen jemaah yang menghadiri kegiatan ta'lim menyatakan bahwa tujuan mereka mengikuti kegiatan di majelis ta'lim adalah tujuan keimanan. Dan tujuan keimanan ini mendominasi dari tujuan lainnya, seperti tujuan untuk memperoleh ilmu pengetahuan umum atau wawasan dan keterampilan. ${ }^{23}$

Majelis ta'lim Selaparang menjadi tempat belajar ilmu agama Islam atau tempat peningkatan pengetahuan keagamaan terkait pokok-pokok ajaran Islam yakni tauhid, figh maupun tasawwuf. Di majelis ta'lim ini juga merupakan tempat pengkaderan bagi calon tokoh agama yang akan memberikan sumbangan pengetahuan bagi jama'ah di kemudian hari. $^{24}$ Menurut hemat peneliti, bahwa peningkatan pengetahuan keagamaan terjadi apabila jama'ah serius mengikuti pengajian yang diselenggarakan oleh pengasuh majelis ta'lim sehingga tercerminnya sikap keagamaan yang menitik beratkan pada nilai-nilai iman, taqwa, dan pengamalan ibadah serta mu'amalah.

2. Tempat Pendidikan Seumur Hidup Berbasis Masyarakat

Dalam pergeseran perkembangan zaman yang semakin canggih dan modern, mendidik anak tanpa ilmu (ilmu keagamaan dan pengetahuan umum) mungkin menjadi salah satu kelemahan bahkan kegagalan pendidik dalam keuarga. Disinilah peran majelis ta'lim menjadi sangat penting bagi jamaah. Disamping itu, lembaga pendidikan nonformal

${ }^{21}$ QS. An-Nahl [16]: 125. Marwah, Al-Qur'an Tajwid Terjemah dan Tafsir untuk wanita, Jakarta: CV Jabal Raudatul Jannah, 2009), h. 281.

${ }^{22}$ Yunan Yusuf, Metode Dakwah, (Jakarta : Prenada Media Group, 2003), hal xii

${ }^{23}$ Helmawati, Pendidikan..., h. 132.

${ }^{24}$ Observasi, bile kedit, Selasa, 5 November 2019. 
yang berbasis masyarakat ini tentu dapat dikatakan sebagai tempat pendidikan seumur hidup. $^{25}$

Dalam pratiknya, jamaah yang mengikuti pengajian di Majelis ta'lim Selaparang tidak dibatasi oleh kelas-kelas - seperti di sekolah -- tidak ada batasan usia, tidak ada jenjang pendidikan, peserta (jamaah) terbuka umum untuk semua kalangan. sehingga tidak menjadi penghambat mereka untuk mengikuti pembinaan keagamaan. ${ }^{26}$

Majelis ta'lim merupakan tempat pengajaran atau pendidikan agama Islam yang paling fleksibel dan tidak terikat waktu ataupun tempat. Majelis ta'lim bersifat terbuka terhadap segala usia, lapisan atau strata sosial, dan jenis kelamin. Fleksibilitas majelis ta'lim inilah yang menjadi kekuatan sehingga mampu bertahan dan merupakan lembaga pendidikan Islam yang paling dekat dengan umat (masyarakat). Dengan demikian, majelis ta'lim menjadi lembaga pendidikan alternatif bagi jama'ah (para orang tua khususnya) yang tidak memiliki cukup tenaga, waktu, biaya dan kesempatan menimba ilmu agama maupun pengetahuan umum pada jalur pendidikan formal. ${ }^{27} \mathrm{Jadi}$, majelis ta'lim merupakan lembaga pendidikan yang paling dekat dengan masyarakat, juga menjadi alternatif bagi masyarakat yang tidak memiliki biaya, tenaga dan waktu dalam menuntut ilmu khususnya ilmu agama. Majelis ta'lim menjadi tempat pendidikan seumur hidup berbasis masyarakat karena pelaksanaan kegiatan majelis ta'lim tidak terikat oleh waktu.

Majelis ta'lim merupakan lembaga pendidikan nonformal dan sekaligus lembaga dakwah yang memiliki peran strategis dan penting dalam pengembangan kehidupan beragama bagi masyarakat. Lembaga pendidikan berbasis masyarakat ini berperan terutama dalam mewujudkan learning society. Urgensi majelis ta'lim yang demikian itulah yang menjadi salah satu solusi bagi masyarakat untuk menambah dan melengkapi pengetahuan yang kurang dan belum sempat diperoleh. ${ }^{28}$

Jika ditelaah secara seksama bahwa majelis ta'lim adalah tempat yang paling banyak memberikan sumbangan untuk pengetahuan masyarakat tentang agama Islam. Sumbangan ini dilakukan karena sebagian besar masyarakat belum memahami secara mendalam terkait dengan ilmu agama Islam secara menyeluruh.

3. Tempat Pendidikan Yang Tidak Membutuhkan Biaya (gratis)

Pendidikan di zaman sekarang, tidak terlepas dari biaya pendidikan yang relatif cukup mahal. Perekonomian masyarakat menjadi tolak ukur terlaksana atau tidaknya pendidikan, disaat kondisi ekonomi masyarakat sedang terpuruk. Majelis ta'lim ini dapat dijadikan sebagai solusi atau menjadi kiblat pencari ilmu agama bagi orang-orang yang

\footnotetext{
${ }^{25}$ Ibid., h. 141.

${ }^{26}$ Khalid Jaelani, Wawancara, bile kedit, Selasa, 5 November 2019.

${ }^{27}$ Ibid., h. 141.

${ }^{28}$ Ibid., h. 142.
} 
kurang mampu khusunya dalam mencapai pendidikan yang lebih baik. Dengan keadaan seperti ini, sebagaimana yang dijelaskan Helmawati, keberadaan majelis ta'lim memberikan kontribusi yang besar dan sangat bermanfaat bagi masyarakat Indonesia, khususnya yang beragama Islam. ${ }^{29}$ Menurut hemat peneliti, bahwa dana/biaya merupakan faktor penting yang menentukan terlaksananya pendidikan. Di zaman sekarang hampir tidak ada yang gratis. Namun, dalam keadaan seperti ini, majelis ta'lim menjadi salah satu tempat pendidikan yang paling mengerti kebutuhan masyarakat, hadir menawarkan pendidikan rendah biaya. Majelis ta'lim Selaparang menggratiskan biaya pendidikan bagi para peserta didiknya. sebagaimana yang diungkapkan oleh Najmuddin sebagai berikut;

Selame ite pade ngaji eleq majelis ta'lim Selaparang ne, endeqt uah jake sugulan biaye maraq entan bayah SPP, bayah persmester, infaq tahunan marak entan eleq sekolah atau madrasah. Ite ngaji gratis yang penting kesadaran ite pade, endeqt uah jaq teendengan kepeng isiq ustadz selame ite ngaji, pokok ngaji eleq majelis ta'lim Selaparang endeqn butub biaye. ${ }^{31}$

Maksud informan di atas adalah selama mengikuti pengajian di majelis ta'lim Selaparang, tidak pernah sang mu'allim meminta diberikan upah atau gaji. Pengajian yang diberikan secara suka rela tanpa mengharap imbalan berupa uang atau gaji.

4. Tempat Terjalinnya Silaturrahim

Majelis ta'lim menjadi tempat ajang silaturrahim untuk semua golongan masyarakat. Jika melihat realita masyarakat Indonesia yang majemuk sekarang ini, di mana masyarakat sudah sangat rentan untuk terpecah belah, maka dengan bersilaturrahmi di majelis ta'lim seharusnya mampu mengeliminasi perpecahan akibat perbedaan yang sesungguhnya merupakan sunnatullah. Ketika manusia mampu menerima perbedaan melalui pengetahuan yang diperoleh dari majelis ta'lim, maka tidak dapat dipungkiri lagi nilai guna majelis ta'lim sebagai aset pemersatu bangsa. ${ }^{32}$

Tempat yang paling memungkinkan bagi terlaksananya silaturrahim yaitu di majelis ta'lim. ${ }^{33}$ Silatiurrahim menjadi salah satu cara agar masyarakat terlepas dari perpecahan yang kerap terjadi akibat perbedaan. Melalui kegiatan-kegiatan yang ada di majelis ta'lim adalah suatu upaya pemersatu umat untuk tetap menjalin silaturrahim bagi masyarakat (jama'ah).

Majelis ta'lim sebagai wadah silaturrahim dan rekreasi rohani. Majelis ta'lim tidak hanya berfungsi sebagai tempat belajar agama Islam, namun juga mampu memberi warna bagi jamaahnya dalam pembinaan solidaritas sosial yang kuat antar umat Islam melalui silaturrahim. Selain itu juga, majelis ta'lim bisa memberikan ruang yang cukup lapang

\footnotetext{
${ }^{29}$ Helmawati, Pendidikan.., h. 131.

${ }^{31}$ Najmuddin, Wawancara, Bile Kedit, Rabu, 6 November 2019.

${ }^{32}$ Helmawati, Pendidikan..., h. x.

${ }^{33}$ Hamazanwadi, Wawancara, Bile Kedit, Selasa 5 November 2019.
} 
dalam menjalankan fungsi rekreasi rohani melalui nasehat-nasehat dan pesan-pesan moral yang diajarkannya. Dalam situasi dan kondisi itulah, melalui majelis ta'lim akan tertanam harmoni sosial yang dapat dipetik oleh semua jamaah yang kemudian mengkondisikan suatu jalinan kebersamaan sebagai hamba-hamba Allah yang sama-sama mempunyai hajat mengisi ruang hati dengan siraman-siraman dakwah Islamiyah. ${ }^{34}$

Majelis ta'lim sebagai tempat silaturrahim dan rekreasi rohaniah bagi jama'ah, selain itu juga menjadi tempat pembinaan solidaritas sosial yang kuat antar umat Islam. Majelis ta'lim juga sebagai perantara bagi jama'ah yang memiliki permasalahan-permasalahan sosial untuk menyelesaikan masalahnya.

\section{Upaya Yang Dilakukan Pengasuh Majelis ta'lim Selaparang Dalam Pembinaan Keagamaan Masyarakat}

Kualitas manusia yang dibutuhkan oleh bangsa Indonesia pada masa yang akan datang adalah yang mampu menghadapi persaingan yang semakin ketat dengan bangsa lain di dunia. Oleh karena itu, agar manusia Indonesia memiliki kualitas yang memadai, harus dihasilkan melalui penyelenggaraan pendidikan yang bermutu. Salah satu tempat penyelenggara pendidikan yang dapat membantu merealisasikan hal tersebut adalah majelis ta'lim. ${ }^{35}$

Pembinaan keagamaan akan berhasil tergantung dari upaya atau usaha yang dilakukan pengasuh majelis ta'lim dalam program-program kegiatan sehari-hari. upaya yang dilaksanakan di majelis ta'lim Selaparang adalah sebagai berikut:

a. Melakukan Kegiatan Pengajian Secara Rutin dan Terjadwal

Salah satu cara memberikan pembinaan keagamaan yang efektif untuk masyarakat yaitu memberikan kegiatan pengajian. Pengajian yang didalamnya membahas mengenai ilmu tafsir, tauhid, fiqh, dan akhlak. Tujuan memberikan pengajian disini menyempurnakan iman dan Islam masyarakat yang sebelumnya masih awam. Ustadz Sami'un ${ }^{36}$, menyebutkan bahwa pengajian yang diselenggarakan di majelis ta'lim Selaparang merupakan salah satu cara memberikan binaan keagamaan bagi jama'ah. Pengajian yang dilaksanakan membahas mengenai ilmu tafsir, tauhid, fiqh dan akhlak. Tujuan diadakannya pengajian yakni memberikan pemahaman dan pendalaman tentang iman dan islam para jama'ah. Hal tersebut diperkuat dengan ungkapan Haji Rahmatullah bahwa upaya pengasuh dilakukan dalam pembinaan keagamaan yang paling penting di majelis ta'lim berupa pengajian. Pengajian yang diselenggarakan oleh ustadz merupakan bimbingan terkait ilmu tauhid agar jama'ah lebih mendalami makna iman dan Islam.

\footnotetext{
34 Maryam, "Peran Majlis Ta’lim Nurul Iman Dalam Pembentukan Sikap Keagamaan Masyarakat Di Rt 10/02 Kelurahan Pagar Dewa Kec Selebar Bengkulu”, Manhaj, Volume 3, Nomor 2, 2018, h. 30.

${ }^{35}$ Helmawati, Pendidik.an..., h. 140.

36 Ustadz Sami'un, wawancara, Bile Kedit, Jum'at, 1 November 2019.
} 
Dalam kajian ilmu fiqh kegiatan ini dilakukan dengan tujuan agar jama'ah dapat menjalankan ibadah sesuai dengan kaidah yang benar. Dan kajian ilmu akhlak dilakukan dengan tujuan agar jama'ah mampu menanamkan nilai moral dan berbudi perkerti yang luhur.

Pengajian menjadi wadah atau media untuk mengingatkan jama'ah kepada firmanfirman Allah yang kemungkinan tidak diketahui. Di samping itu, pengajian dapat menjadi jalan penghubung atau untuk mempererat silaturahmi. Oleh karena itu, pengajian dapat digunakan sebagai sarana untuk membangun solidaritas sosial. Pengajian tidak sematamata berhubungan dengan aspek religius saja, tetapi terkait pula dengan aspek sosial, pendidikan, dan politik. ${ }^{37}$

Tradisi “tuan guru"38 Lombok sepulang dari pengembaraannya menuntut ilmu, adalah membentuk pengajian-pengajian kecil di tempat tinggalnya dengan sistem khalaqah (duduk bersila), dimana tuan guru dan santri yang mengaji di hadapan tuan guru dengan materi-materi pengajian yang paling mendasar, mulai dari materi ketauhidan dengan membuka kitab arab melayu. ${ }^{39}$

Jejak "tuan guru" dalam memberikan pengajian-pengajian di tempat tinggalnya merupakan tradisi turun temurun yang dilakukan oleh ustadz atau yang memiliki ilmu agama yang mumpuni. Estapet pemberian pengajian ini menjadi salah satu usaha yang paling mendasar untuk memberikan pembinaan keagamaan kepada warga masyarakat supaya terwujudnya masyarakat beriman dan bertakwa.

b. Pemberian Konseling

Disamping terlaksananya pengajian di majelis ta'lim Selaparang, pembinaan juga dilakukan melalui pemberian bimbingan dan konseling kepada jama'ah yang memiliki masalah pribadi. Biasanya konseling ini diberikan setelah pengajian selesai. Masalah yang ditanyakan berkisar masalah pribadi, masalah keluarga maupun masalah warga masyarakat yang tidak menjadi jama'ah di majelis ta'lim Selaparang, tujuan dari menanyakan masalah kepada ustadz agara masalah tersebut diselesaikan di majelis ta'lim.

Pemberian bimbingan dan konseling ini dilakukan agar jama'ah terbantu dalam masalah yang dihadapi. Sebagaimana yang diungkapkan oleh Saharuddin kepada peneliti bahwa majelis ta’lim menjadi tempat terlaksananya pengajian sekaligus menjadi tempat

37 Suprapti dkk, "Pengajian Sebagai Pembentuk Karakter Islami Bagi Generasi Bangsa Di Desa Ngreco Kecamatan Tegalombo Pacitan", Jurnal Mahasiswa TARBAWI: Journal on Islamic Education Vol 3 No (2) 2019, h. 88

${ }^{38}$ Tuan guru (istilah masyarakat Sasak NTB) dan ulama' adalah gelar ahli agama Islam dalam kepustakaan Barat. Bagi masyarakat Islam di pedesaan, seorang Tuan Guru memegang peranan penting untuk membentengi umat dari citacita Islam terhadap ancaman-ancaman sekuler dari luar. Tuan Guru merupakan pemimpin kharismatik dalam bidang agama. Ia fasih dan mempunyai kemampuan yang cermat dalam membaca pemikiran pengikut-pengikutnya. (Fahrurrozi Dahlan, Sejarah Perjuangan dan Pergerakan Dakwah Islamiyah Tuan Guru Haji Muhammad Mutawalli di Pulau Lombok, (Jakarta: Penerbit Sentra Media, 2006), h. 1).

${ }^{39}$ Fahrurrozi Dahlan, Sejarah Perjuangan dan Pergerakan Dakwah Islamiyah Tuan Guru Haji Muhammad Mutawalli di Pulau Lombok, (Jakarta: Penerbit Sentra Media, 2006), h. 42. 
pemberian bimbingan dalam menyelesaikan masalah terkait kehidupan jama'ah, keluarga maupun warga masyarakat umum yang tidak menjadi bagian di majelis ta'lim Selaparang. Bimbingan yang dilakukan tidak terkait waktu karena disetiap ada kesempatan bimbingan langsung diberikan. ${ }^{40}$

Mengembangkan fungsi konseling. Sebagai salah satu lembaga pendidikan non formal, majelis ta'lim bertanggung jawab untuk mendidik dan membantu jamaahnya untuk dapat beradaptasi dengan lingkungan masyarakatnya dan mampu memecahkan berbagai persoalan hidup yang dihadapinya. Melalui kegiatan ta'lim-muta'alim (belajar mengajar) yang dikemas sedemikian rupa diharapkan dapat membantu jamaah yang mengalami persoalan-persoalan kehidupan, baik pribadi maupun sosial. Dalam situasi seperti inilah peran dan fungsi konseling akan terasa diperlukan oleh berbagai pihak yang terlibat di majelis ta'lim, terutama para jamaahnya. ${ }^{41}$

Majelis ta'lim sebagai tempat pemberian bimbingan dan konseling terhadap jama'ah dan masyarakat. Dalam kegiatan belajar mengajar diharapkan dapat membantu jama'ah yang mengalami persoalan-persoalan entah itu persoalan pribadi maupun sosial. Peran sekaligus fungsi konseling akan sangat terlihat pada penyelesaian permasalahanpermasalahan yang ada.

\section{Hambatan-Hambatan dalam Pembinaan Keagamaan di Majelis ta'lim Selaparang}

Dalam pembinaan keagamaan terdapat hambatan-hambatan yang arah timbulnya dapat berasal dari dalam (internal) maupun dari luar (eksternal).

1. Faktor Internal

Faktor internal adalah faktor penghambat terjadinya pemberian binaan yang dialami oleh jama'ah maupun pengasuh majelis ta'lim seperti sakit, terkena musibah, dan pengasuh maupun jama'ah yang mempunyai keperluan yang mendadak sampai-sampai tidak bisa mengikuti pengajian. Faktor yang menjadi penghambat pembinaan keagamaan masyarakat yang dipengaruhi oleh beberapa faktor yang sifatnya internal di antaranya sebagai berikut :

a. Faktor Pendidikan

Pendidikan adalah salah satu proses yang bertujuan untuk membentuk pola perilaku salah satunya adalah pendidikan agama. Proses itu biasanya membutuhkan peran pendidik, tetapi pendidik yang bisa mendidik diri sendiri setelah berjumpa dengan pengalaman pendidik. Oleh karena itu, pendidik lebih menekankan kepada pemberian kesempatan agar seseorang mengalami sendiri atau pengalaman agama. Seorang

\footnotetext{
40 Ustadz Sami'un, wawancara, Bile Kedit, Jum'at, 1 November 2019.

${ }^{41}$ Maryam, "Peran Majlis Ta'lim Nurul Iman Dalam Pembentukan Sikap Keagamaan Masyarakat Di Rt 10/02 Kelurahan Pagar Dewa Kec Selebar Bengkulu”, Manhaj, Volume 3, Nomor 2, 2018, h. 30.
} 
pembina atau pendidik, mempunyai tanggung jawab yang sangat besar dalam membina agar selalu melaksanakan perbuatan-perbuatan yang baik, bersikap sopan, menghargai orang lain dan sebagainya. ${ }^{42}$

Menurut hemat peneliti, pendidikan masyarakat yang beragam sangat berpengaruh dalam pelaksanaan kegiatan pengajian di majelis ta'lim, dengan pendidikan dasar yang masih minim (awam) akan menghambat pemberian materi-materi yang cukup tinggi. Oleh sebab itu, dalam pemberian materi-materi pengajian disaring oleh pengasuh majelis ta'lim karena pendidikan masyarakat yang relatif rendah.

\section{b. Faktor Tingkat Usia}

Hubungan antara perkembangan usia dengan perkembangan jiwa keagamaan tampaknya tidak dapat dihilangkan begitu saja. Bila konversi agama dipengaruhi oleh sugesti, maka konversi agama akan lebih banyak terjadi pada anak-anak, karena dilihat usia tersebut lebih mudah menerima sugesti. Namun kenyataannya hingga usia paruh bayapun masih terjadi konversi agama, Seperti yang terjadi pada Martin Luther dan Al-Ghazali. ${ }^{43}$

Menurut hemat peneliti, jama'ah yang aktif mengikuti kegiatan pengajian rutin dan terjadwal yaitu jama'ah yang berusia 30 tahun sampai 40 tahun, sedangkan di atas 40 tahun sangat jarang mengikuti pengajian karena sakit. Walaupun ada sebagian dari jama'ah yang umurnya lebih dari 60 tahun mengikuti pengajian. Dalam hal ini dapat disimpulkan bahwa usia jama'ah menjadi penghambat pembinaan keagamaan.

c. Faktor Kondisi Kejiwaan

Kondisi kejiwaan ini terkait dengan kepribadian sebagai faktor intern. Sigmun Freud mengemukakan bahwa gangguan kejiwaan ditimbulkan oleh konflik dan akan menjadi sumber gejala kejiwaan yang abnormal. Penyakit atau faktor genetik kondisi system saraf diperkirakan menjadi sumber munculnya perilaku yang abnormal. Dengan demikian, sikap manusia ditentukan oleh stimulant (rangsangan) lingkungan yang dihadapi saat itu. ${ }^{44}$

Kaitannya dengan temuan penelitian, kondisi kejiwaan para jama'ah sangat berpengaruh dalam menerima isi pengajian yang diberikan pendidik, sebab kalau kondisi kejiwaan masyarakat dalam keadaan sehat akan memudahkan jama'ah dalam memahami pembahasan-pembahasan yang disampaikan pendidik. Begitu juga dengan kondisi kejiwaan jama'ah yang ada masalah, akan menjadi penghambat dalam menerima dan memahami pembahasan-pembahasan yang disampaikan pendidik.

42 Muslih TB dkk, Peranan Pendidikan Agama Islam Dalam Mencegah Kenakalan Remaja (Juvenile Delinguency), Jakarta:Rajawali Pers, 2008. h. 160.

${ }^{43}$ Ibid., h.162.

44 Ibid., h.163. 
2. Faktor Eksternal

Faktor eksternal merupakan faktor yang mempengaruhi terhambatnya pemberian pembinaan keagamaan di majelis ta'lim seperti, alasan pekerjaan, penyelenggaraan peringatan hari besar Islam (PHBI) seperti maulid Nabi Muhammad SAW., Isra' dan Mi'raj, Nuzulul Qur'an, dan begawe. Pengasuh majelis ta'lim mengungkapkan faktor penghambat terjadinya pembinaan atau pengajian rutin diliburkan dengan alasan adanya peringatan hari besar Islam (PHBI) yang diselenggarakan oleh setiap masyarakat yang memaksa kegiatan pengajian atau pembinaan keagamaan diliburkan. ${ }^{45}$ Pernyataan tersebut dipertegas dengan ungkapan Najmuddin bahwa warga masyarakat yang mengikuti pengajian di majelis ta'lim Selaparang adakalanya pengajian diliburkan karena adanya peringatan hari besar Islam antara lain, seperti: peringatan Maulid Nabi, Isra' Mi'raj dan kegiatan warga masyarakat yaitu begawe. Pengajian diliburkan karena warga masyarakat tidak dapat mengikutinya.

Faktor eksternal adalah faktor- faktor yang menyebabkan terjadinya hambatan dalam pembinaan jiwa keagamaan masyarakat yang berasal dari luar atau lingkungannya. faktor yang menghambat pembinaan jiwa keagamaan masyarakat yang dipengaruhi oleh faktor internal diantaranya sebagai berikut :

a. Kesibukan masyarakat dalam mencari nafkah ${ }^{46}$. Sebagian besar masyarakat Dusun Bile Kedit yang menjadi jama'ah mata pencahariannya terkait erat dengan alam. Pekerjaan dengan mengelola sumber alam tentu memerlukan tenaga dan waktu yang cukup besar bagi masyarakat. Secara tidak langsung hal tersebut menyebabkan kelelahan bagi masyarakat setelah bekerja. Kondisi ini kemudian menjadi hambatan bagi masyarakat untuk menghadiri berbagai pembinaan yang dilakukan oleh pengasuh majelis ta'lim.

b. Lingkungan masyarakat

Lingkungan masyarakat merupakan unsur yang berpengaruh dalam norma dan tata nilai dalam kehidupan sehari-hari. Lingkungan masyarakat yang memiliki tradisi keagamaan berpengaruh terhadap kehidupan keagamaan terkondisi dalam tatanan nilai maupun institusi keagamaan. Keadaan seperti ini bagaimanapun sangat berpengaruh dalam pembentukan jiwa warganya. ${ }^{47}$

Menurut hemat peneliti, pembinaan keagamaan menjadi mudah terealisasi apabila dilakukan di lingkungan yang baik. lingkungan yang baik menjadi salah satu penyebab tersalurnya pendidikan dengan sangat cepat, karena dengan dukungan dari lingkungan akan mempermudah peserta didik memahami materi agama yang diberikan.

${ }^{45}$ Ustadz Sami'un, Wawancara, Bile kedit, Sabtu, 2 November 2019.

46 Harles anwar, dan Muhaimin, "Dakwah Melalui Pembinaan Keagamaan Terhadap Masyarakat Muslim Pedalaman Oleh Penyuluh Agama Islam Non Pns Kecamatan Tebas, Sambas”, Bimbingan Penyuluhan Islam, Vol. 1, No. 1 Januari-Juni 2019, H. 31.

47 Muslih, TB dkk, Peranan.., h.165. 
Adapun solusi yang dilakukan pengasuh majelis ta'lim selaparang dalam mengatasi hambatan-hambatan pembinaan keagamaan sebagai berikut:

a. Memberikan bimbingan kepada warga masyarakat yang datang ke majelis ta'lim selaparang dengan tujuan agar permaslahan yang dialami masyarakat diselesaikan pengasuh, walaupun kegiatan pengajian rutin sedang libur.

b. Memberikan arahan kepada jama'ah yang membawa persoalan tentang agama Islam dengan cara mencarikan ibarat-ibarat (materi-materi) untuk menyelesaikan persoalan yang ditanyakan.

\section{SIMPULAN}

Berdasarkan temuan data dan hasil pembahasan yang disajikan pada bab sebelumnya, maka peneliti dapat menarik kesimpulan sebagai berikut:

1. Peran majelis ta'lim selaparang dalam pembinaan keagamaan masyarakat adalah Sebagai Tempat Peningkatan Pengetahuan Keagamaan, Tempat Pendidikan Seumur Hidup Berbasis Masyarakat, Tempat Pendidikan Yang Tidak Membutuhkan Biaya, Tempat Terjalinnya Silaturrahim.

2. Upaya yang dilakukan pengasuh majelis ta'lim Selaparang dalam pembinaan keagamaan masyarakat sebagai berikut; Melakukan kegiatan pengajian secara rutin dan terjadwal, Pemberian konseling kepada masyarakat.

3. Hambatan-hambatan dalam pembinaan keagamaan masyarakat sebagai berikut:

a. Faktor internal, antara lain; pengasuh sakit atau jama'ah sakit dan adanya musibah.

b. Faktor eksternal, diantaranya; alasan pekerjaan jama'ah, penyelenggaraan hari besar Islam (PHBI) dan begawe.

\section{DAFTAR PUSTAKA}

Anwar, Harles, dan Muhaimin, "Dakwah Melalui Pembinaan Keagamaan Terhadap Masyarakat Muslim Pedalaman Oleh Penyuluh Agama Islam Non Pns Kecamatan Tebas, Sambas ”, Bimbingan Penyuluhan Islam, Vol. 1, No. 1 Januari-Juni 2019.

Arikunto, Suharsimi. Prosedur Penelitian: Suatu Pendekatan Praktik. Jakarta: Rineka Cipta, 2006. Aziz Ahyadi, Abdul. Psikologi Agama (Kepribadian Muslim Pancasila). Bandung: CV Sinar Baru, 2005.

Dahlan, Fahrurrozi. Sejarah Perjuangan dan Pergerakan Dakwah Islamiyah Tuan Guru Haji Muhammad Mutawalli di Pulau Lombok. Jakarta: Penerbit Sentra Media, 2006.

Djam'an Satori, Aan Qomariah. Metode Penelitian Kualitatif. Bandung: Alfabeta, 2014.

Hadi, Machmud. "Model Pendidikan Pada Majelis ta'lim Kota Kendari”. Jurnal Al Izzah. Vol. 8, No. 1, Juni 2013. 
Hasbullah. Sejarah Pendidikan Islam di Indonesia (Lintasan Sejarah Pertumbuban dan perkembangan). Jakarta: PT. Raja Grafindo Persada. 1995.

Helmawati. Pendidikan Nasional dan Optimalisasi Majelis ta'lim, Peran Aktif Majelis ta'lim Meningkatkan Mutu Pendidikan. Jakarta: Rineka Cipta. 2013.

Marwah. Al-Qur'an Tajwid Terjemah dan Tafsir untuk wanita. Jakarta: CV Jabal Raudatul Jannah, 2009.

Marzuki, Ahmad. 'Dinamika Dan Peran Majelis ta'lim Dalam Meningkatkan Pengetahuan Keagamaan Di Wilayah Suku Tengger". Jurnal Mafhum, Volume 1 Nomor 2, November 2016.

Mubarok, Achmad. Psikologi Dakwah. Jakarta : Prenada Media Group, 2009.

Muslih, TB. Aat Syafaat \& Sohari Sahroni. Peranan Pendidikan Agama Islam Dalam Mencegah Kenakalan Remaja (Juvenile Delinguency) Jakarta:Rajawali Pers, 2008.

Nasution, Harun. Islam di tinjau dari Berbagai aspek. Jakarta : UI Press 1985.

Nata, Abuddin. Tafsir Ayat-Ayat Pendidikan. Jakarta: Rajawali Pers, 2014.

Nazir. Metode Penelitian. Bogor: Ghalia Indonesia, 2005.

Pulungan, Muhammad Yusuf. "Peran Majelis ta'lim Dalam Membina Keluarga Sakinah Masyarakat Muslim Di Kota Padang Sidimpuan”. Jurnal Tazkir Vol. 9 No. 1 JanuariJuni 2014.

Ramayulis. Ilmu Pendidikan Islam. Jakarta: Kalam Mulia, 1994.

Ramlah. "Majelis ta'lim Dan Peranannya Dalam Peningkatan Dakwah Di Kecamatan Wara Selatan Kota Palopo". Journal of Social-Religion Research, Palita. Vol. 2, No. 1, April 2017.

Sudaryono. Metode Penelitian Pendidikan. Jakarta: Kencana, 2016.

Suprapti dkk, "Pengajian Sebagai Pembentuk Karakter Islami Bagi Generasi Bangsa Di Desa

Ngreco Kecamatan Tegalombo Pacitan”. Jurnal Mahasiswa TARBAWI: Journal on Islamic Education Vol 3 No (2) 2019.

Syafi'i Ma'arif, Ahmad. Islam dan Politik : Upaya Membingkai Peradaban. Jakarta : Pustaka Dinamika, 1999.

Tohirin. Metode Penelitian Kualitatif dalam Pendidikan dan Bimbingan Konseling. Jakarta: PT. Raja Grafindo, 2012.

Warson Munawir, Ahmad. Kamus Al-Munawmir. cet. XIV: Yogyakarta: Pustaka Progressif, 1997.

Yusuf, Yunan. Metode Dakwah. Jakarta : Prenada Media Group, 2003. 